\title{
AZ AMMÓNIA KIBOCSÁTÁSÁNAK CSÖKKENTÉSE ÉS A NITROGÉNMENEDZSMENT PROBLÉMÁJA NAPJAINKBAN
}

\author{
Tárnok Balázs - Kujáni Katalin
}

\begin{abstract}
Absztrakt: Az ammónia (NH3) a nitrogéntartalmú szerves vegyületekből, elsősorban a karbamid és a fehérjék biológiai lebontásakor jön létre. A mezőgazdasági eredetű kibocsátások közvetlenül és közvetve az állati emésztőrendszerből, a trágya tárolásából és a talajból származhatnak. Az állattartó telepekből származó kibocsátásokra az állatfajok, a takarmány (N-kiválasztás hatása), az épület jellemzői (padló, szellőzés, hőmérséklet) és a trágya tárolása (külső hőmérséklet, a lefedettséghez használt anyag) hatással vannak. Az egyes légköri szennyező anyagok nemzeti kibocsátásainak csökkentéséről szóló 2284/2016-os, napjainkban is hatályos EU irányelv 2010-től kezdődően állapítja meg a kapcsolódó határértékeket. Ezen irányelv Magyarország tekintetében többek között (kéndioxid, nitrogén-oxid), elöírja az ammónia kibocsátásának a csökkentését, amely az agrár-ágazat szempontjából a legjelentősebb. Az elöírt határértékek a 2005-ös értékekhez viszonyítva 2020-ra 10\%-os, míg 2030-ra 32\%-os csökkentést jelentenek. Összegezve, az ammónia mitigációja (csökkentése) globális méretü, agrárágazati probléma. Kutatásommal egy átfogó képet kívánok alkotni a jelenleg hatályos kibocsátás-csökkentési szabályozásról nemzeti és nemzetközi szinten. A publikáció egy szakirodalmi áttekintést kíván adni az ammónia-emisszió csökkentésével foglakozó nemzetközi tudományos értekezésekről.
\end{abstract}

\begin{abstract}
Ammonia (NH3) is derived from nitrogen-containing organic compounds, primarily from biological degradation of urea and proteins. Agricultural emissions can originate directly and indirectly from the animal's digestive tract, from the manure storage and from the soil. Emissions from livestock farms are affected by animal species, feed (N-effect), building characteristics (floor, ventilation, temperature) and manure storage (outside temperature, material used for coverage). The Directive on National Emission Ceilings, which is still in force today, sets the relevant limit values for emissions of certain air pollutants from 2010 onwards. This directive requires, among other things, Hungary (sulfur dioxide, nitrogen oxide) to reduce emissions of ammonia, which is the most significant for the agricultural sector. The required limits are $10 \%$ by 2020 and $32 \%$ by 2030 compared to 2005 values. In summary, reducing ammonia mitigation is a global problem. With my research, I intend to create a comprehensive picture of the current emission reduction regulations at national and international level. The publication is intended to provide an overview of international scientific discussions on ammonia emission reduction.
\end{abstract}

Kulcsszavak: ammónia, kibocsátás-csökkentés, légszennyezés, környezetvédelmi politika

Keywords: ammonia, emission reduction, air pollution, environmental policy

\section{Bevezetés}

Az ammónia kibocsátásának csökkentésével kapcsolatban a NECD (Nemzeti kibocsátási határértékekről szóló 2284/2016-os EU irányelv) hatályos. Az irányelv nemzeti kibocsátási határértékeket határoz meg bizonyos levegőszennyező anyagok összes kibocsátásaira, amelyeket a tagállamoknak tiszteletben kell tartaniuk. Az e tárgyban jelenleg hatályos irányelv 2010-től kezdődően állapít meg határértékeket, melyek az elmúlt években elősegítették a kén-dioxid (savas esőket okozó anyag), az ammónia, a nitrogén-oxidok és az illékony szerves vegyületek (oldószerekből, közúti jármüvekből, háztartási fütő- és áramtermelő rendszerekből származó szennyező anyagok) kibocsátásainak csökkentését. A fentiek alapján a magyar agrárágazat szempontjából legjelentősebb az ammóniakibocsátás csökkentése, melyek 
mértéke a 2005-ös értékekhez viszonyítva 2020-ra 10\%-os, míg 2030-ra 32\%-os emisszió csökkentés.

$\mathrm{Az}$ ammónia $\left(\mathrm{NH}_{3}\right)$ a nitrogéntartalmú szerves vegyületekből, elsősorban a karbamid és a fehérjék biológiai lebontásakor jön létre. Az emlősállatok szervezete kiválasztja a nitrogén többletet, mint karbamidot a vizeletben. Azonban az ürülék is tartalmaz nitrogént fehérjeként, valamint különböző szerves vegyületekként. A legtöbb ammónia-kibocsátás a karbamid hidrolíziséből származik, az ammóniát termelö ureáz enzim jelenlétében (Bernhard Osterburg, 2018).

Az állattartó telepekből származó ammónia-kibocsátás csökkentésére irányuló intézkedések közé tartozik a trágya korszerübb kezelése az épületben, mint például a vizelet elválasztása, a trágya hütése, a légszürők használata és a trágya tárolóinak lefedése. Ezen túl a kijuttatásból származó kibocsátás csökkentésére vonatkozó szabályozások a trágya talajba történő bedolgozására, vagy a hígtrágya talajba injektálására, és a hígításra, valamint savanyításra irányulnak (Bernhard Osterburg, 2018).

\section{2. ábra: A mezőgazdaságból származó ammónia-kibocsátás országonként, 2011-ben és 2016-ban (kg / ha hasznosított mezőgazdasági területeken)}

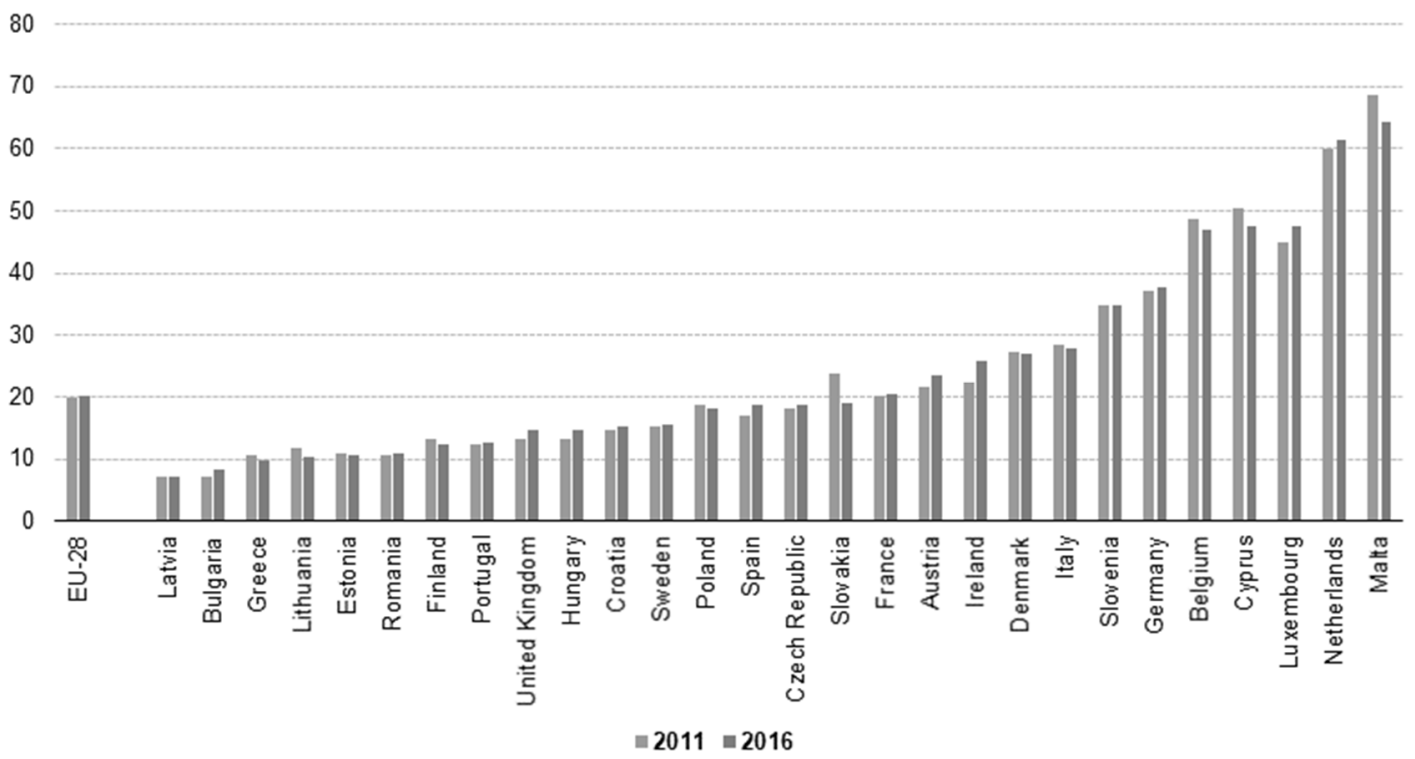

Forrás: Eurostat, 2019.

\section{Anyag és módszer}

Kutatásommal egy átfogó képet kívánok alkotni a jelenleg hatályos kibocsátáscsökkentési szabályozásról, valamint a tudományos eredményeken alapuló útmutatókról nemzeti és nemzetközi szinten. A publikációban egy szakirodalmi áttekintést kívánok adni az ammónia-emissziócsökkentéssel kapcsolatos eljárásokról, valamint a kibocsátáscsökkentési intézkedésekről Magyarország vonatkozásában. 
Jelen tanulmányban három ország (név szerint Hollandia, Dánia és Finnország) jelenleg is hatályos intézkedéseit mutatom be. Az országokra a választás azért esett, mert jelenleg az Uniós szinten zászlóshajónak mondhatóak a mezőgazdasági eredetü káros anyagok csökkentésének tekintetében.

\section{Eredmények}

\subsection{Hollandia integrált szemléletủ szabályozása}

Hollandiában 1984 óta nemzeti intézkedéseket hoztak a trágya és a mütrágya felhasználás környezeti hatásainak csökkentésére. A jelenlegi holland megközelítés olyan intézkedések kombinációját jelenti, amelyek a termelést és a talajok és a vizek terhelésének csökkentésére irányuló intézkedéseket szabályozzák. 2008-ban lépett hatályba az Európai Unió (továbbiakban EU) ammónia emissziós határértékek elérése érdekében az állategységre vonatkozó kibocsátási normákra vonatkozó irányelve. A 2010-2019-es időszakra maximum 128 kilotonna ammóniát írtak elő. A 2020-2024 közötti időszakban 13\%-al a 2025-2029 közötti időszakban pedig 25\% kal tervezik csökkenteni a kibocsátási szintet a 2005-öshöz képest (Hans J.M. Van Grinsvena et. al. 2016)

A holland kutatások megerösítették azt a korábbi következtetést, hogy az alacsony kibocsátású gyepgazdálkodási technikák hatékonyan csökkentik az ammónia veszteséget miközben növelik a gyepnövekedéshez szükséges nitrogén rendelkezésre állását (Hans J.M. Van Grinsvena et. al. 2016).

A fentieken túl a holland trágyázási és mütrágyázási törvény (holland nevén: Meststoffenwet) az uniós szintủ Nitrát Direktíva holland végrehajtásának szerves része. A szabályzás többek között meghatározza a kijuttatható nitrogén és foszfát mennyiségét, valamint a kijuttatás módját is, amelyet mütrágya és szerves trágya formájában lehet alkalmazni gyep- illetve szántóterületen.

\subsection{Dánia állattenyésztéssel kapcsolatos intézkedései}

A dán mezőgazdasági szabályozás egyik központi célkitüzése a nitrogénciklus optimalizálása az agrártermelési rendszeren belül azáltal, hogy növeli a szerves forrásokból származó tápanyagok felhasználását, pl. az állati hígtrágyát a rendszerben, és korlátozza a mủtrágyák rendszerbe való beépítését egy fenntartható mennyiségre, miközben csökkenti a rendszerből származó veszteséget környezetileg kompatibilis szintre (Ministry of Environment and Food of Denmark, 2017).

A szabályok elöírják, hogy a terület minimális méretére vonatkozóan az állattartó gazdaságnak rendelkezésre kell állnia az üzemmérethez mért trágyatárolóval is. A követelmény az élőállat-egységek hektáronkénti (Állategység (ÁE) / ha) korlátozása. Az állattenyésztés egyes szakaszaihoz (pl.: tárolás) kapcsolódó nitrogén tartalom alapján, a legjobb modern termelési rendszernél a legalacsonyabb ammónia-kibocsátással, 1 állategységnél (ÁE) a 100 kg N-ről lehet beszélni. Ezáltal végrehajtják a nitrátokról szóló irányelv (91/676 EGK Irányelv) azon követelményét, mely szerint a hektáronkénti trágya mennyisége max. $170 \mathrm{~kg}$ nitrogén hatóanyag (továbbiakban N), ami a legjobb termelési rendszerben 1,7 ÁE / 
ha. 2017 augusztusától az ÁE követelményeket kg-ban hektáronkénti korlátként definiálják. Ha az állati trágyát a gazdaságon kívül szállítják, az átruházott állattenyésztési egységek számát a nitrogéntartalom alapján kell kiszámítani (Ministry of Environment and Food of Denmark, 2017).

\subsection{Finnország kibocsátást csökkentő szabályozása}

Finnországban az ammónia-kibocsátás több mint 90 százaléka származik mezögazdasági szektorból, ezért a kibocsátás csökkentésére irányuló intézkedések nagy részét az ágazatra kell irányítani. A mezőgazdaságban az ammónia az állattenyésztésből: a trágya tárolásából és kijuttatásából származik. A mezőgazdaságban az ammónia-kibocsátás csökkentését célzó leghatékonyabb intézkedések az állati trágyázásra és az azzal kapcsolatos tevékenységekre vonatkoznak. Az ammónia-kibocsátás csökkenthető az állatok takarmányozásával kapcsolatos intézkedésekkel is, de ezek szabályozása és az elért hatások felmérése nehezebb, mint a trágyakezeléssel kapcsolatos intézkedések esetében. (Ministry of Agriculture and Forestry of Finnland, 2018).

A Finnország ammónia-kibocsátási leltárának elkészítéséhez használt korábbi modell dokumentációját csak finn nyelven tették közzé. A jelentés magába foglalja az ammónia-kibocsátásról, az ammónia-párolgásáról, az emissziós forrásokról, a korábbi, a mezőgazdaságból származó ammónia-kibocsátás Finnországra és más országokban történő becslésére vonatkozó adatok dokumentációjának alapos irodalmi áttekintését, valamint a lehetséges csökkentési intézkedésekről szóló információkat. A kiadvány egy aktualizált és a termelők számára is könnyen használható modellt is dokumentál a trágyagazdálkodásból származó ammóniakibocsátás kiszámításához az állattartó teleptől a trágya kijuttatásáig. A kiadvány tartalmazza a különböző ammónia-modellekben alkalmazott paramétereket Finnországban és más országokban is, mint például az állattartó telepekben történő kipárolgást (Ministry of Agriculture and Forestry of Finnland, 2018).

\subsection{Ammóniacsökkentési intézkedések Magyarországon}

A Magyarországon végbemenő rendszerváltozást és az abból következő (drasztikusnak mondható) állatállomány csökkenése következtében 1990 és 2016 között 42\%-kal csökkent az ammónia emisszió. Emellett jelentős a szennyezödés a mütrágya-felhasználásból is. (Eöry és Kujáni, 2019a). Ez azonban jelentősen függ olyan tényezőktől, mint a mütrágya típusa, az időjárás, vagy a talaj adottságai. Jó példa rá, hogy a karbamid alapú mütrágyákból következő kibocsátás sokkal jelentősebb más mütrágyatípusukhoz képest (Eőry és Kujáni, 2019b).

Az ammónia csökkentésére 2015 óta nemzeti program előkészítése folyik az Agrárminisztériumban a NEC Irányelv végrehajtásaként. Az egyeztetésben részt vettek egyes kutatóintézetek, a Nemzeti Agrárgazdasági Kamara, az Országos Meteorológiai Szolgálat, valamint egyéb szakmai szervezetekkel. A szakpolitikai célként egy olyan program elkészítése van megjelölve, amely elősegíti a nitrogénfelhasználásból eredendő költségek csökkentését, és egészséges fenntarthatóbb agrárágazat létrehozását (Eőry és Kujáni, 2019a). 
Az Országos Levegőterhelés Csökkentési Program, Mezőgazdasági Alprogramja a következö területek szabályozására fog kitérni:

- - helyes mezőgazdasági gyakorlat

- - alacsony fehérje tartalmú takarmányozás

- - modern trágyatárolás

- - emisszió-csökkentett kijuttatási módszerek

- - mütrágya felhasználás

Magyarország számára a legkiemeltebb intézkedési területek a karbamid-alapú mütrágyák, a szervestrágya kijuttatás és az alacsony fehérjetartalmú takarmányozás környezetvédelmi szempontból felelős és termelőbarát szabályozása.

Végezetül egy táblázatban foglaltam össze a vizsgált országok ammóniacsökkentési intézkedéseit. Ez alapján megállapítható, hogy a trágyatárolók lefedése, és a kijuttatással kapcsolatos kibocsátáscsökkentés általánosan bevett módszerek. Ezzel szemben az alacsony fehérjetartalmú takarmányozás, valamint a karbamidalapú műtrágyák kiváltása nem jellemző minden országra.

\begin{tabular}{|c|c|c|c|c|c|}
\hline ország/intézkedés & $\begin{array}{c}\text { Trágyatárolók } \\
\text { lefedett- } \\
\text { ségének } \\
\text { növelése }\end{array}$ & $\begin{array}{c}\text { Közös tápanyag- } \\
\text { menedzsemt } \\
\text { szabályozás }\end{array}$ & $\begin{array}{c}\text { Modern } \\
\text { kijuttatási } \\
\text { technológiák }\end{array}$ & $\begin{array}{c}\text { Alacsony } \\
\text { fehérjetartalmú } \\
\text { takarmányozás }\end{array}$ & $\begin{array}{c}\text { Karbamid- } \\
\text { alapú } \\
\text { mútrágyák } \\
\text { kiváltása }\end{array}$ \\
\hline Hollandia & $\mathrm{X}$ & $\mathrm{X}$ & $\mathrm{X}$ & $\mathrm{X}$ & \\
\hline Dánia & $\mathrm{X}$ & $\mathrm{X}$ & $\mathrm{X}$ & & $\mathrm{X}$ \\
\hline Finnország & $\mathrm{X}$ & & $\mathrm{X}$ & $\mathrm{X}$ & \\
\hline Magyarország & $\mathrm{X}$ & & $\mathrm{X}$ & & \\
\hline
\end{tabular}

Forrás: saját szerkesztés

\section{Következtetések}

A nemzeti szabályozások legfontosabb elemeit áttekintve a mezőgazdaságban az ammónia-kibocsátás csökkentését célzó leghatékonyabb intézkedések az állati trágyázásra és az azzal kapcsolatos tevékenységekre vonatkoznak. A nemzeti szabályozások vizsgálata alapján elmondható, hogy az ammónia-kibocsátás csökkenthető az állatok takarmányozásával kapcsolatos intézkedésekkel is, de ezek szabályozása és az elért hatások felmérése nehezebb, mint a trágyakezeléssel kapcsolatos intézkedések esetében.

Az ammónia-kibocsátás csökkentésére vonatkozó legfontosabb intézkedések a következők:

- - a hígtrágya és a vizelet injektálásos és csúszócsoroszlyás kijuttatása

- - trágyatárolók fedése.

A fontosabb irányelvek ökológiai céljainak nagy az átfedése, ezért a különböző tápanyagforrások csökkentése több országban egységes szabályozott politikákban zajlik, amely holisztikus megközelítést igényel. 
A fentieken túl az intézkedések megvalósításához kulcsfontosságú tényező lenne a költségek újraelosztása az érintett termelők között, amely egyúttal a Közös Agrárpolitika (KAP) és a környezeti irányelvek jobb integrációját is jelentené.

\section{Irodalomjegyzék}

Bernhard Osterburg, (2018), Policy and administrative measures to prevent ammonia emissions, TAIEX-EIR PEER 2 PEER Multi Country Workshop on ammonia emissions from agriculture, 2018 10. 30.

Hans J. M. Van Grinsvena, Aaldrik Tiktaka, Carin W. Rougoorb (2016) Evaluation of the Dutch implementation of the nitrates directive, the water framework directive and the national emission ceilings directive ). pp. 69-84 NJAS - Wageningen Journal of Life Sciences

78. szám, 2016 szeptember

Ministry of Environment and Food of Denmark (2017): Overview of the Danish regulation of nutrients in agriculture \& the Danish Nitrates Action Programme, pp. 1-23, 2017. június

Ministry of Agriculture and Forestry of Finnland, (2018): Action plan to reduce ammonia emissions from agriculture in Finnland . pp:7-23. 1B/2018, ISBN: 978-952-453-973-9 Helsinki

Eöry Viktória, Dr. Kujáni Katalin (2019a): Ammónia-kibocsátás csökkentése: nem csak a gazdának fontos (https://www.agronaplo.hu/szakfolyoirat/2019/02/aktualis/ammonia-kibocsatascsokkentese-nem-csak-a-gazdanak-fontos).pp. 25-26. 2019. február, Agronapló

Eőry Viktória, Dr. Kujáni Katalin (2019b): A műtrágyázás is felelős a levegőszennyezésért! Mit tehetünk ellene? (https://agronaplo.hu/szakfolyoirat/2019/03/aktualis/a-mutragyazas-is-felelosa-levegoszennyezesert-mit-tehetunk-ellene) pp. 15-16. 2019. március, Agronapló

Eurostat (2019)

https://ec.europa.eu/eurostat/statistics-

explained/index.php?title=File:Ammonia_emissions_from_agriculture,_by_country,_2011_and _2016_(kg_per_ha_of_utilised_agricultural_area).png. Utolsó elérés: 2019. március 27.) 